\title{
Lee Raleigh Shugart
}

\author{
Chris Theodorakis ${ }^{1} \cdot$ John Bickham ${ }^{2} \cdot$ Steve Bartell ${ }^{3}$
}

Accepted: 28 October 2021 / Published online: 13 November 2021

(c) The Author(s), under exclusive licence to Springer Science+Business Media, LLC, part of Springer Nature 2021

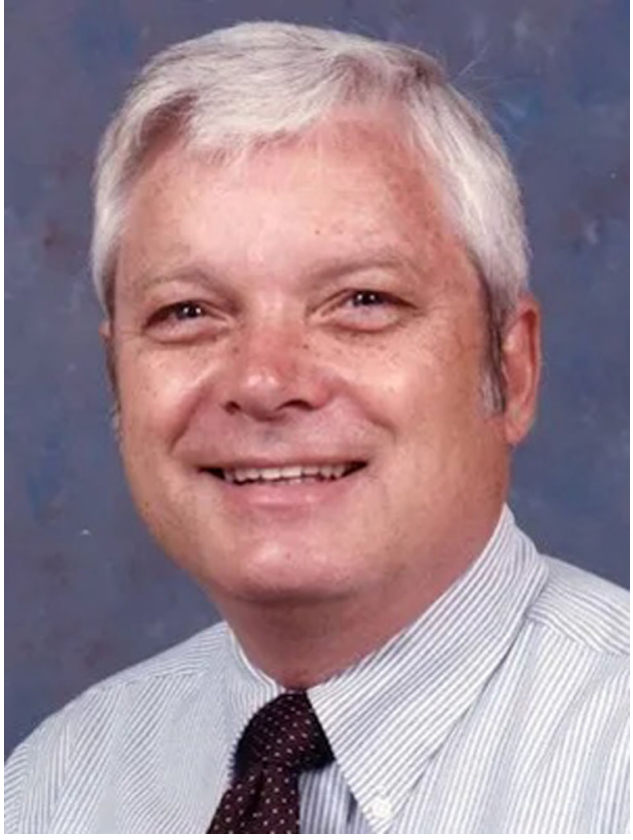

Lee R. Shugart passed away on September 20, 2021, much to the great sorrow of his family, friends, and colleagues. Lee was the Editor-in-Chief and sole surviving founder of this journal-following the death in 2001 of his friend, colleague, and Ecotoxicology co-founder David Peakall. The success of Ecotoxicology is due in great part to Lee's dedication to the quality and recognition of this journal, and he would take great pride every time the impact factor increased. It is because of his diligent efforts that Ecotoxicology is what it is today, and Lee worked tirelessly to promote the journal and serve as Editor-in-Chief until his death.

Chris Theodorakis

ctheodo@siue.edu

1 Southern Illinois University Edwardsville, Edwardsville, IL, USA

2 Professor Emeritus, Texas A\&M University, College Station, TX, USA

3 Cardno, Maryville Tennessee, Maryville, TN, USA
Lee was born on December 23, 1931, in Corbin, Kentucky, USA. There, he attended St. Camillus Academy, and graduated as the valedictorian of his class. He then attended East Tennessee State University in Johnson City, Tennessee, where he earned a B.S. in Chemistry in 1951. After graduation, he enlisted in the U.S. Navy and served in the Korean Conflict. His Naval service lasted for six years, and he achieved the rank of Lieutenant as a Line Officer. After leaving the Navy, he enrolled in graduate school, and graduated with an M.S. in Biochemistry in 1962 and a $\mathrm{PhD}$ in Microbiology in 1965, both from the University of Tennessee Knoxville. His master's thesis was entitled "A Study of Ashing and Colorimetric Procedures in the Determination of Protein-Bound Iodine", and his PhD dissertation was "A Study of the Proteinase from Streptococcus faecalis var. liquefaciens".

Shortly after graduation, he started developing his career as a world-renowned scientist. From 1965 to 1967, he was a post-doctoral fellow at Oak Ridge National Laboratory in Oak Ridge, Tennessee, USA (ORNL). He became a staff scientist there in 1967, which continued until his retirement in 1996. He started in the Biology Division before moving to the Environmental Sciences Division (ESD) in the mid1980s. There, he reached the rank of Senior Research Staff Member and Group Leader. Additionally, he was on an OffSite Assignment for the Pentagon from 1995 - 1996.

Lee's research centered on biomonitoring efforts that contributed to the remediation and restoration of contaminated sites in Oak Ridge, the United States, and around the world. He played a major role in developing the concept of biomarkers of environmental contamination and their use in biomonitoring and risk assessment. Lee was a leading authority in DNA damage and a major contributor to the development of the fields of genetic ecotoxicology and evolutionary toxicology. His main focus was developing assays for investigating DNA strand breakage, DNA adducts, contaminant protein modifications, and other biomarkers in fish, invertebrates, rodent models, and humans. Prior to the 1980s, his work largely focused on biochemistry of tRNA and nucleotides/nucleosides in bacterial and 
eukaryotic research models. He was also one of the first to demonstrate epigenetic effects of contaminants in native fish species, having published a paper showing that benzo [a]pyrene caused global hypomethylation in bluegill sunfish (Lepomis macrochirus; Shugart 1990). Sadly, he retired before he could develop this line of research further, otherwise he probably would have also been a driving force in ecotoxicological epigenetics.

Lee was a highly productive scientist and a prolific writer. He was sole, lead, or co-author of at least 125 peerreviewed publications including book chapters, encyclopedia entries, conference proceedings, and manuscripts in internationally-renowned journals, Plus, he was the coeditor of 3 peer-reviewed books on biomarkers or toxicology. He also authored or co-authored numerous editorials, one book review, and 4 obituaries in Ecotoxicology. In addition, he authored or co-authored many ORNL technical reports of his research, most of which were published in the scientific literature as well. His publications focused not only on ecotoxicology and DNA damage, but also protein biosynthesis, mechanisms of enzyme action, and nucleic acid biochemistry.

He was equally productive in a number of professional activities other than publication. First, besides his role in Ecotoxicology, he was on the editorial board of the journal "Biomarkers", an Associate Editor for the 2nd edition of the "Encyclopedia of Toxicology", and - from 2009 to 2018.the series editor of the book series "Emerging Topics in Ecotoxicology: Principles, Approaches and Perspectives". Second, he served as advisor to governmental and nongovernmental organizations, including as a Consultant to the Science Advisory Board of the U.S. Environmental Protection Agency and as a Scientific Assistant to the Deputy Assistant to the Secretary of Defense for Nuclear, Chemical and Biological Matters/Counter Proliferation. Importantly, Lee also advised and collaborated with Greenpeace in monitoring contaminants and DNA adducts in beluga whales (Delphinapterus leucas) in the St. Lawrence River (located on the US/Canadian border). Third, he was the chairman, organizer or co-organizer for several international workshops and symposia. These included "The International Symposium for Nondestructive Biomarkers in Vertebrates" (Sienna, Italy, 1992); the "NATO Advanced Research Workshop on Biomarker Research and Application in the Assessment of Environmental Health" at the Netherlands Institute of Sea Research (Texel, The Netherlands, 1991); the "14th Symposium on Aquatic Toxicology and Risk Assessment", sponsored by the American Society for Testing and Materials (San Francisco, California,1990); and the "Symposium on Biological Markers of Environmental Contaminants" (Los Angeles, California, 1988). Fourth, he was active in several professional societies, including the American Chemical Society, Sigma
$\mathrm{Xi}$, the American Society of Biochemistry \& Molecular Biology, and the Society of Environmental Toxicology \& Chemistry (SETAC, for which he was a member since 1987). In fact, from 1987 to 1996, the ORNL ESD was very visible at SETAC North America conferences, and Lee was a major contributor to this. He was listed as co-author on multiple poster or oral presentations during these years. Finally, Lee's professional activities led him to visit many parts of the world. He had research collaborators in Italy, The Netherlands, Russia, and Portugal. He also traveled to these countries-as well as Spain, India, and China-to impart his knowledge, experience, and expertize in the form of invited seminars and educational courses.

Lee was heavily involved in academic and educational activities as well. He served as an adjunct Associate Professor for the University of Tennessee Knoxville Departments of Plant Sciences and Ecology and Evolutionary Biology, the Graduate School for Biomedical Sciences, the College of Veterinary Medicine, and the Center for Environmental Biotechnology. In this capacity, Lee was a valued advisor and research mentor for many undergraduate, master's, and PhD students. He was also affiliated with Oak Ridge Associated Universities in the capacity of a supervisor for post-doctoral fellows.

Lee's professional endeavors did not end with his retirement from Oak Ridge National Laboratory. Besides retaining a leading role in Ecotoxicology, he remained active in his consulting firm, LR Shugart and Associates, which he founded in 1995. The activities of his consulting firm included providing advice, guidance, and expertize for the Canadian Wildlife Service; the United Nations Environmental Program; the City of Porto, Portugal; Exxon Mobil (largely in association with the Valdez oil spill); and USGS (Greater Everglades Restoration Project). Another focus of this firm was providing educational and manuscript-editing services for students and researchers around the world. Finally, LR Shugart and Associates was a vehicle for establishing REACH Risk, a contractual service for contributing to risk assessments associated with European Union Registration and Assessment of Chemicals (REACH). In addition to his consulting business, Lee participated in a number of scientific workshops, such as in Goa, India (Marine Pollution and Ecotoxicology, 2004), Lisbon, Portugal (CICTA 2008), Beijing, China (China-U.S. Joint Workshop on Bioenergy Consequences for Global Environmental Change, 2008), Nanjing, China (EHPC 20, 2008) and Huaibei, China (International Ecopolis Forum, 2009). Furthermore, he was instrumental in helping to organize the International Workshop on Ecotoxicity in Guangzhou, China in 2010, in collaboration with UT Knoxville, Purdue University, South China Sea Institute of Oceanology, and the Chinese Academy of Science. 
On his professional achievements, Gary Sayler-professor emeritus of University of Tennessee Knoxville (UT) and long-time colleague of Lee-writes: "I joined the University of Tennessee Knoxville in 1975 and Lee was already a well-respected Staff Scientist at ORNL and an Adjunct faculty member in the Graduate Program in Ecology (GPE) at the University. The GPE was an early successful model of interdisciplinary education working across institutional boundaries i.e., UT/ORNL/TVA [Tennessee Valley Authority]/USDA [US Department of Agriculture]. Lee was a terrific mentor in cross disciplinary student training and PI collaboration. In the 1980s, led by the GPE, the University initiated a new focus in Environmental Toxicology and Lee had a significant advisory role in curriculum planning and faculty recruitment. His interdisciplinary strengths led to Adjunct Professor status participation across several departments in the College of Arts and Sciences, the College of Veterinary Medicine and the College of Agriculture. From 2010 to 2018, Lee was an active participant in the UT-led China/US Joint Research Center for Ecosystem and Environmental Change (JRCEEC). At invitation of the Chinese Academy of Science, Lee joined UTK faculty and ORNL staff in JRCEEC organized field site and lecture tours across China. He additionally provided invaluable technical editing service to many foreign researchers and greatly improved their opportunity to publish in leading international journals. In this and other capacities, Lee was a valued advisor and research mentor for undergraduate, master's, and $\mathrm{PhD}$ students. As a member of the UT/ORNL Science Alliance, Lee helped in reducing institutional barriers and promoting collaborations in joint initiatives such as the Radiation Biology Program, the Genome Sciences Program, and the Center for Environmental Biotechnology".

Besides his professional relationships, Lee's interpersonal relationships were also well-appreciated. He had perennial energy, an infectious laugh, a zest for life, a great sense of humor, and a charming personality. He was kind, generous, warm, hospitable, patient, and easy-going (most of the time). He was well-liked or well-loved by friends and colleagues, not only in the U.S., but in many countries around the world. He loved to garden, and was particularly proud of the tomatoes he raised in his greenhouse. He even constructed an ingenious contraption for mechanically pollinating them because of the lack of insect pollinators in the greenhouse (CT; pers. obs.). In fact, in the 1970s, he owned several greenhouses where he would hydroponically raise tomatoes to sell at the Oak Ridge farmer's market. He very much enjoyed fine dining, as well as visiting and traveling with, and cooking for, friends and family. In addition, he was an avid golfer and stamp and coin collector. He also enjoyed spending time outdoors-whether it was in his beautiful yard and gardens at his home in Knoxville,
Tennessee, at his lovely cabin in the hills of Townsend, Tennessee, in the Smoky Mountains (Tennessee), or on his many travels. And he always had a good story to tell.

Most important in his life, however, was his family. He is survived by Shirley Shugart (his wife of 37 years), his three daughters (with former wife Mary Susan Ryburn, now deceased), five grandchildren, and four great-grandchildren. He will be very much missed by all.

Below are some personal statements from friends and colleagues, followed by a list of his publications.

\section{Personal Statements}

Chris Theodorakis writes:

"My first experiences with Lee were as a $\mathrm{PhD}$ advisor and my first post-doc mentor, but to me he was more than that. The German word for PhD advisor is 'Doktorvater', which literally translated means "doctor father", and that pretty much sums it up. He was a colleague and dear friend for over 30 years. Every time I saw him (which was far too infrequently), he had a smile on his face, a funny story, a good laugh, and presents for my children. I am fortunate to have known him. He was always kind and patient with me - a mentor beyond measure. He gave me a chance when many would not, and for that I am eternally grateful. And he introduced me to John Bickham (my second post-doc mentor), which was instrumental in starting my career. I literally would not be where I am today without him. I will always have precious memories of spending time with him and Shirley at his home, joining them on their travels, and sharing dinners with them and John at SETAC meetings. In fact, the last time I saw him was when I had dinner with him, Shirley, John, and Lindy Paul at the 2018 SETAC meeting in Sacramento, CA. These meetings will not be the same without him. I am very regretful that I was not able to visit with him more recently (because of staying in Germany for family reasons, and the pandemic). He will live on in his family, his accomplishments, the people that he trained, and the many lives he touched. As they say at Greek funerals: 'everlasting be his memory'. He will be sorely missed. Rest in peace, old friend".

John Bickham writes:

"A good part of my career was devoted to studying the genetic effects of environmental contaminants in natural populations of fish and wildlife, and no one helped me more in this endeavor than Lee Shugart. Lee was my close friend and mentor for 33 years, from the time of our chance meeting in Chapel Hill, NC in 1988 until his death in 2021. He graciously included me in so many of the meetings and symposia that he organized during those years, which had a profound impact on my career. I co-authored 5 papers with Lee, but that doesn't begin to tell the story of his deep impact on my thinking with regards to the importance of genetic effects and especially the need to develop sensitive 
biomarkers to measure them. As it always is with teachers and mentors, you owe them a debt that can never be repaid. I'll miss Lee not only for his unsurpassed knowledge of the field, but also the warmth of his friendship. My wife Pat and I travelled with Lee and Shirley to so many places and had so many wonderful experiences. These included The Netherlands, Italy, Spain, Portugal, China, and many places here in the U.S. These trips always provided the opportunity to exchange scientific information, meet new people in the field, and to catch up and renew our personal friendships. I greatly appreciate Lee's contributions to my career, for his help for the careers of my grad students Karen McBee and Cole Matson, and for sending Chris Theodorakis to my lab as a postdoctoral researcher. Two things that I cherish the most and of which I am most proud, are co-authoring a paper with Lee and my daughter Amy, and that Cole has followed Lee as the editor of Ecotoxicology".

Gabriele Rutz writes:

"Lee Shugart was my husbands 'Doktorvater', and when I met him 20 years ago it felt like they were not just colleagues but family. A family I was immediately accepted into. Lee was one of the warmest, sincerest, most modest people I have ever met and he will be greatly missed. He shared his knowledge, his home and his heart with us and will forever be one of the most influential mentors and role model who will stay with us always".

Marie-Agnes Coutellec writes:

"I met Lee in Seville (SETAC Europe meeting 2010), as he came to Carlos Barata and myself, after a symposium on evolutionary toxicology (to which you were both invited participants) to invite us to co-edit a special issue on the topic, and thereby provided a new impulse to a research field quite understudied since a few seminal papers in the early nineties. To me, this marked the beginning of an ongoing relationship with Lee, through my activity as associate editor for the journal Ecotoxicology. Since then, he has always shown confidence and been supportive to me, and from his caring attitude I could feel a sensitive personality, who will always inspire me greatest respect and gratitude.

My deepest compassion to his family".

Marcela Ines Schneider writes:

"I am so sorry to hear this sad news regarding Dr Shugart. I had a great appreciation for him without knowing him personally. I can remember when he invited me to belong to the Ecotoxicology Editorial Board in 2008 considering that being a South American scientist and woman could be a great contribution to the journal. Also, he highlighted the relevance for the Journal to include researchers from worldwide for the Ecotoxicology EB. His passion for science and the journal's role in spreading knowledge was admirable. I raise a prayer in his memory, praying that his soul is at peace. My deepest condolences to his family".
Joana Luísa Pereira writes:

"Dr. Shugart invited me to join the Editorial board of Ecotoxicology as an Associate Editor back in 2011, possibly following my contribution as a reviewer-he never disclosed the motivation for assigning such a young researcher to such a position. But he trusted in my capacity to assume the position competently and since then I was gifted with his close presence and incredible support in dissolving any insecurities while developing and delivering the requested editorial work for the Journal. Lee guided and mentored me through a stimulating learning and maturation process in this context. While discussing about different editorial issues, he was also incredible generous in sharing his experienced perspectives on any other interesting parallel issues. Although (unfortunately) I never had the chance to meet Lee in person, he has been and will continue to be a remarkable influence and a reference to me as a scientist and as an editor toward high-levelled quality standards, deep respect for all actors involved, honesty and passion in science and scientific publication. I will miss his written words but Lee's messages and consequent lessons learnt will be a living legacy forever".

\section{Compliance with ethical standards}

Conflict of interest The authors declare no competing interests.

Publisher's note Springer Nature remains neutral with regard to jurisdictional claims in published maps and institutional affiliations.

\section{Professional Publications}

Shugart L (2017) Emerging advances and challenges in pesticide ecotoxicology. Ecotoxicology 26:293-294

Shugart LR, Theodorakis CW, Bickham JW (2010) Evolutionary toxicology. In: DeWoody JA, Bickham JW, Michler CH, Nichols KM, Rhodes GE, Woeste KE (eds.) Molecular Approaches in Natural Resource Conservation and Management. Cambridge University Press, Cambridge, U.K., p 320-362

Stewart CN, Shugart L, Liu GS, Zhuang J, Ma Y, Tuskan GA, Meilan R, Gentry RW, Sayler GS (2010) China-US Workshop on Biotechnology of Bioenergy Plants. Ecotoxicology 19:1-3

Shugart LR (2005) Acetone. In: Wexler P, Anderson BD, Gad SC, Hakkinen PB, Kamrin M, De Peyster A, Locey B, Pope C, Mehendale HM, Shugart LR (eds.) Encyclopedia of Toxicology., Vol. 1, 2nd edn. Academic Press, Cambridge, MA, USA, p 27-28

Shugart LR (2005) Bacillus cereus. In: Wexler P, Anderson BD, Gad SC, Hakkinen PB, Kamrin M, De Peyster A, Locey B, Pope C, Mehendale HM, Shugart LR (eds.) Encyclopedia of Toxicology., Vol. 1, 2nd edn. Academic Press, Cambridge, MA, USA, p 203

Shugart LR (2005) Biomarkers, Environmental. In: Wexler P, Anderson BD, Gad SC, Hakkinen PB, Kamrin M, De Peyster A, Locey B, Pope C, Mehendale HM, Shugart LR (eds.) Encyclopedia of Toxicology., Vol. 1, 2nd edn. Academic Press, Cambridge, MA, USA, p 287-290

Shugart LR (2005) Bioremediation. In: Wexler P, Anderson BD, Gad SC, Hakkinen PB, Kamrin M, De Peyster A, Locey B, Pope C, Mehendale HM, Shugart LR (eds.) Encyclopedia of 
Toxicology., Vol. 1, 2nd edn. Academic Press, Cambridge, MA, USA, p 297-298

Shugart LR (2005) Clostridium perfringens. In: Wexler P, Anderson BD, Gad SC, Hakkinen PB, Kamrin M, De Peyster A, Locey B, Pope C, Mehendale HM, Shugart LR (eds.) Encyclopedia of Toxicology., Vol. 1, 2nd edn. Academic Press, Cambridge, MA, USA, p 625-625

Shugart LR (2005) E. coli. In: Wexler P, Anderson BD, Gad SC, Hakkinen PB, Kamrin M, De Peyster A, Locey B, Pope C, Mehendale HM, Shugart LR (eds.) Encyclopedia of Toxicology., Vol. 2, 2nd edn. Academic Press, Cambridge, MA, USA, p115-116

Shugart LR (2005) Echinacea. In: Wexler P, Anderson BD, Gad SC, Hakkinen PB, Kamrin M, De Peyster A, Locey B, Pope C, Mehendale HM, Shugart LR (eds.) Encyclopedia of Toxicology., Vol. 2, 2nd edn. Academic Press, Cambridge, MA, USA, p 116

Shugart LR (2005) Mercaptans. In: Wexler P, Anderson BD, Gad SC, Hakkinen PB, Kamrin M, De Peyster A, Locey B, Pope C, Mehendale HM, Shugart LR (eds.) Encyclopedia of Toxicology., Vol. 3, 2nd edn. Academic Press, Cambridge, MA, USA, p 31-32

Shugart LR (2005) Nitrogen oxides. In: Wexler P, Anderson BD, Gad SC, Hakkinen PB, Kamrin M, De Peyster A, Locey B, Pope C, Mehendale HM, Shugart LR (eds.) Encyclopedia of Toxicology., Vol. 3, 2nd edn. Academic Press, Cambridge, MA, USA, p 244-245

Wexler P, Anderson BD, Gad SC, Hakkinen PB, Kamrin M, De Peyster A, Locey B, Pope C, Mehendale HM, Shugart LR, eds. (2005) Encyclopedia of Toxicology, 2nd edn. Academic Press, Cambridge, MA, USA.

Costa FO, Neuparth T, Theodorakis CW, Costa MH, Shugart LR (2004) RAPD analysis of southern populations of Gammarus locusta: comparison with allozyme data and ecological inferences. Marine Ecol Progress Series 277:197-207

Costa FO, Cunha MR, Neuparth T, Theodorakis CW, Costa MH, Shugart LR (2004) Application of RAPD DNA fingerprinting in taxonomic identification of amphipods: a case-study with Gammarus species (Crustacea: Amphipoda). J Marine Biol Assoc UK 84:171-178

Shugart LR, Theodorakis CW, Bickham AM, Bickham JW (2003) Genetic effects of contaminant exposure and potential impacts on animal populations. In: Hoffman DJ, Rattner BA, Burton Jr GA, Cairns Jr J (eds.) Handbook of Ecotoxicology. Lewis Publishers, Boca Raton FL, USA, p 1129-1147

Costa FO, Neuparth T, Costa MH, Theodorakis CW, Shugart LR (2002) Detection of DNA strand breakage in a marine amphipod by agarose gel electrophoresis: exposure to X-rays and copper. Biomarkers 7:451-463

Peakall D, Shugart L (2002) The Human Genome Project. Ecotoxicology 11:7

D'Surney SJ, Shugart LR, Theodorakis CW (2001) Genetic markers and genotyping methodologies: an overview. Ecotoxicology 10:201-204

Dahl CR, Bickham JW, Wickliffe JK, Custer TW, Shugart L (2001) Cytochrome b sequences in black-crowned night-herons (Nycticorax nycticorax) from heronries exposed to genotoxic contaminants. Ecotoxicology 10:291-297

Shugart LR (2000) DNA damage as a biomarker of exposure. Ecotoxicology 9:329-340

Theodorakis CW, Elbl T, Shugart LR (1999) Genetic ecotoxicology IV: survival and DNA strand breakage is dependent on genotype in radionuclide-exposed mosquitofish. Aquat Toxicol 45:279-29

Shugart LR (1998) Structural damage to DNA in response to toxicant exposure. In: Forbes VE (ed.) Genetics and Ecotoxicology. Taylor \& Francis, Philadelphia, p 151-168

Shugart L, Cibulka J, Boruvka L, Curdova E, Holsbeek L, Kahru A, Kotelevtsev S, Kratz W, Kubiznakova J, Walker C (1999) Report of the working group on Northern Bohemia. In: Peakall DB, Walker $\mathrm{CH}$, Migula P (eds.) Biomarkers: a pragmatic basis for remediation of severe pollution in eastern Europe. Springer, Dordrecht, p 229-277

Shugart L, Theodorakis C (1998) New trends in biological monitoring: application of biomarkers to genetic ecotoxicology. Biotherapy 11:119-127

Theodorakis CW, Shugart LR (1998) Natural selection in contaminated environments: A case study using RAPD genotypes. In: Forbes VE (ed.): Genetics and Ecotoxicology Taylor \& Francis, Philadelphia, p 123-149

Theodorakis CW, Bickham JW, Elbl T, Shugart LR, Chesser RK (1998) Genetics of radionuclide-contaminated mosquitofish populations and homology between Gambusia affinis and $G$. holbrooki. Environ Toxicol Chem 17:1992-1998

Theodorakis CW, Shugart LR (1998) Genetic ecotoxicology III: the relationship between DNA strand breaks and genotype in mosquito fish exposed to radiation. Ecotoxicology 7:227-235

Everaarts JM, Den Besten PJ, Hillebr MTJ, Halbrook RS, Shugart LR (1998) DNA strand breaks, cytochrome P-450-dependent monooxygenase system activity and levels of chlorinated biphenyl congeners in the pyloric caeca of the seastar (Asterias rubens) from the North Sea. Ecotoxicology 7:69-79

Peakall DB, Shugart LR (1998) Biomarkers* In RA Meyers (ed.) Encyclopedia of Environmental Analysis and Remediation. In: Meyers RA (ed.) Encyclopedia of Environmental Analysis and Remediation. John Wiley \& Sons Inc, New York, NY, p 732-755

Theodorakis CW, Shugart LR (1997) Genetic ecotoxicology II: population genetic structure in mosquitofish exposed in situ to radionuclides. Ecotoxicology 6:335-354

Theodorakis CW, Blaylock BG, Shugart LR (1997) Genetic ecotoxicology I: DNA integrity and reproduction in mosquitofish exposed in situ to radionuclides. Ecotoxicology 6:205-218

Egorov VG, Nalivaiko SE, Pavlenko VS, Rzshevsky OS, Gordon EB, Cooper LW, Grebmeier JM Shugart LR (1997) Submersible UVB spectroradiometer using an acouto-optic tunable fiber. In: Ackleson SG, Frouin RJ (eds.) Ocean Optics XIII, vol 2963, International Society for Optics and Photonics, Cardiff, Wales, UK, p 664-669

Shugart LR, Theodorakis C (1996) Genetic ecotoxicology: The genotypic diversity approach. Comparative Biochemistry and Physiology Part C: Pharmacology. Toxicol Endocrinol 113:273-276

Blaylock BG, Theodorakis CW, Shugart LR (1996) Biological effects of ionizing radiation. In: Amiro B, Johansson G, Larsson, C-M, Luening M (eds.) Protection of the Natural Environment. International Symposium on Ionising Radiation Proceedings, V. 1., International Atomic Energy Agency, Vienna, p 39-50

Shugart LR (1996) Application of the alkaline unwinding assay to detect DNA strand breaks in aquatic species. In: Ostrander G (ed.) Techniques in Aquatic Toxicology. CRC Press, Boca Raton, FL, p 205-218

Boon JP, Everaarts JM, Ten Hallers Sleiderink HM, Beyer J, Gokøyr A, Klungsøyr J, Wilhelmsen S, Halbrook RS, Shugart LR, Ariese F (1995) The integrated North Sea Programme 1991-92: Theme microcontaminants. Marine Environ Res 1:345-346

Shugart LR (1995) Environmental genotoxicology. In: Rand GM (ed.) Fundamentals of Aquatic Toxicology. Taylor \& Francis, Philadelphia, p 405-419

Shugart LR (1995) Biomarkers of DNA damage. In: Bloom AD, de Serres F (eds.) Ecotoxcity and Human Health: A Biological Approach to Environmental Remediation. CRC Press, Boca Raton, FL, p 123-141

Shugart LR (1995) Molecular and biochemical responses to toxic agents. In: Newman MC (ed.) Quantitative Ecotoxicology: A Hierarchical Approach. Lewis Publishers Inc, Boca Raton, FL, p 133-161 
Martineau D, De Guise S, Fournier M, Shugart L, Girard C, Lagace A, Bel P (1994) Pathology and toxicology of beluga whales from the St. Lawrence Estuary, Quebec, Canada. Past, present and future. Sci Total Environ 154:201-215

Everaarts JM, Sleiderink HM, Den Besten PJ, Halbrook RS, Shugart LR (1994) Molecular responses as indicators of marine pollution: DNA damage and enzyme induction in Limanda limanda and Asterias rubens. Environ Health Persp 102(suppl 12):37-43

Shugart LR (1994) Hemoglobin adducts. In: Fossi MC, Leonzio C (eds.) Nondestructive Biomarkers in Vertebrates. Lewis Publishers, Boca Raton, FL, p 159-168

Shugart L (1994) Genotoxic responses in blood. In: Fossi MC, Leonzio C (eds.) Nondestructive Biomarkers in Vertebrates. Lewis Publishers, Boca Raton, FL, p 131-145

Anderson S, Sadinski W, Shugart L, Brussard P, Depledge M, Ford T, Hose J, Stegeman J, Suk W, Wirgin I, Wogan G (1994) Genetic and molecular ecotoxicology: a research framework. Environ Health Perspect 102(suppl 12):3-8

Shugart LR (1994) Biological monitoring. In: Fossi C, Renzoni A, Lari L, Matte N (eds.) Contaminants in the Environment: A Multidisciplinary Assessment of Risks to Man and Others Organisms. Lewis Publishers, Boca Raton, FL, p 29-36

Shugart L, Theodorakis C (1994) Environmental genotoxicity: probing the underlying mechanisms. Environ Health Perspect 102(suppl 12): $13-17$

Theodorakis CW, D'Surney SJ, Shugart LR (1994) Detection of genotoxic insult as DNA strand breaks in fish blood cells by agarose gel electrophoresis. Environ Toxicol Chem 13:1023-1031

Adams SM, Cada GF, Greeley Jr MS, Shugart LR (1993) Evaluating effects of environmental stress on fish communities using multiresponse indicators. In: Hildebrand SG, Cannon JB (eds.) Environmental Analysis, The NEPA Experience. Lewis Publishers, Boca Raton, FL, p 170-177

Bél P, DeGuise S, Girard C, Lagace A, Martineau D, Michaud R, Shugart LR (1993) Toxic compounds and health and reproductive effects in St. Lawrence beluga whales. J Great Lakes Res 19:766-775

Everaarts JM, Shugart LR, Gustin MK, Hawkins WE, Walker WW (1993) Biological markers in fish: DNA integrity, hematological parameters and liver somatic index. Marine Environ Res 35:101-107

Halbrook RS, McCarthy JF, Shugart LR (1993) Conceptual strategy for development and application of a biomarker-based biomonitoring program. In: Peakall DB, Shugart RL (eds.) Biomarkers, Springer, Berlin, p 79-109

Meyers-Schöne L, Shugart LR, Walton BT, Beauchamp JJ (1993) Comparison of two freshwater turtle species as monitors of radionuclide and chemical contamination: DNA damage and residue analysis. Environ Toxicol Chem 12:1487-1496

Peakall DB, Shugart RL, eds. (1993) Biomarkers: Research and Application in The Assessment of Environmental Health. NATO ASI Series-Series H: Cell Biology, Springer-Verlag, Berlin

Shugart LR (1993) State of the art-ecological biomarkers. In: Travis CC (ed.) Use of Biomarkers in Assessing Health and Environmental Impacts of Chemical Pollutants. Springer, Boston MA, p $237-245$

Shugart LR, Halbrook RS (1993) Use of biomarkers to assess environmental health. In: Vo-Dinh T (ed.) International Conference on Monitoring of Toxic Chemicals and Biomarkers: 23-26 June 1992 Berlin, FRG (Proceedings Europe), 1716 International Society for Optics and Photonics. Bellingham, Washington, USA, p 199-204

Adams SM, Crumby WD, Greeley Jr MS, Shugart LR, Saylor CF (1992) Responses of fish populations and communities to pulp mill effluents: a holistic assessment. Ecotoxicol Environ Safety 24:347-360
Beauchamp JJ, McCarthy JF, Rosenblatt DH, Shugart LR (1992) Statistical design for sampling and analysis of animal populations for chemical contamination. Risk Analysis 12:233-238

Halbrook RS, Guzman CE, Wilkinson KJ, Watson AP, Munro NB, Shugart LR (1992) Rapid whole-blood cholinesterase assay with potential use for biological monitoring during chemical weapons disposal. J AOAC Intern 75:549-553

Halbrook RS, Shugart LR, Watson AP, Munro NB, Linnabary RD (1992) Characterizing biological variability in livestock blood cholinesterase activity for biomonitoring organophosphate nerve agent exposure. J Am Veterinary Med Assoc 201:714-725

Loar JM, Adams SM, Bailey RD, Blaylock BG, Boston HL, Cox DK, Huston MA, Kimmel BL, Olsen CR and Ryon MG (1992) Second report on the Oak Ridge National Laboratory Biological Monitoring and Abatement Program for White Oak Creek Watershed and the Clinch River (Report No. ORNL/TM-10804). Oak Ridge National Laboratory, Oak Ridge, TN

McCarthy JF, Shugart LR, Jimenez BD (1992) Biomarker-based biomonitors for evaluating health and ecological effects of environmental contaminants. In: Hazardous Waste Site Investigations: Toward Better Decisions. CRC Press Inc. Boca Raton, FL, p 177-207

Shugart LR (1993) State of the art - ecological biomarkers. In: Travis C.C. (ed) Use of Biomarkers in Assessing Health and Environmental Impacts of Chemical Pollutants. NATO ASI Series (Series A: Life Sciences), vo`hhhh 250. Springer, Boston, MA, p 237-245

Shugart LR, Bickham J, Jackim G, McMahon G, Ridley W, Stein J, Steinert S (1992) DNA alterations. In: Huggett RJ (ed.) Biomarkers: Biochemical Physiological Histological Markers of Anthropogenic Stress. Lewis Publishers, Boca Raton, FL, p $125-154$

Shugart LR, McCarthy JF, Halbrook RS (1992) Biological markers of environmental and ecological contamination: an overview. Risk Analysis 12:353-360

Theodorakis CW, D'surney SJ, Bickham JW, Lyne TB, Bradley BP, Hawkins WE, Farkas WL, McCarthy JF, Shugart LR (1992) Sequential expression of biomarkers in bluegill sunfish exposed to contaminated sediment. Ecotoxicology 1:45-73

McCarthy JF, Gardner H, Wolfe MJ, Shugart LR (1991) DNA alterations and enzyme activities in Japanese medaka (Oryzias latipes) exposed to diethylnitrosamine. Neurosci Biobehav Rev 15:99-102

McCarthy, JF, Halbrook RS, Shugart LR (1991). Conceptual strategy for design, implementation, and validation of a biomarker-based biomonitoring capability (Report No. ORNL/TM-11783). Oak Ridge National Laboratory, Oak Ridge, TN

Munro NB, Shugart LR, Watson AP, Halbrook RS (1991) Cholinesterase activity in domestic animals as a potential biomonitor for nerve agent and other organophosphate exposure. J Am Veterinary Med Assoc 199:103-115

Shugart, LR (1991). Dinitrotoluene in deer tissues (Report No. ORNL/ M-1765). Oak Ridge National Laboratory, Oak Ridge, TN

Shugart LR, D’Surney SJ, Gettys-Hull C, Greeley MS Jr (1991). Biological (molecular and cellular) markers of toxicity. Final report, September 15, 1988-September 14, 1991 (Report No. ORNL/M-1845). Oak Ridge National Laboratory, Oak Ridge, TN

McCarthy JF, Shugart L, Jimenez-Velez B (1991) Biomarker-based biomonitoring for evaluating health and ecological effects on environmental contamination (Report No. CONF-900556-2), Oak Ridge National Laboratory, Oak Ridge, TN

Adams SM, Shugart LR, Hinton DE (1990) Application of bioindicators in assessing the health of fish populations experiencing contaminant stress. In McCarthy JF, Shugart LR (eds.) Biomarkers of Environmental Contamination. Lewis Publishers, Boca Raton, FL, p 333-353 
Hunsaker CT, McCarthy JF, Shugart LR, O’Neill RV (1990) Indicators relevant to multiple resource categories. In: Hunsaker C, Carpenter D (eds.) Ecological Indicators for the Environmental Monitoring and Assessment Program. US Environmental Protection Agency, Washington, DC, p 1-25

McCarthy JF Shugart LR, eds. (1990) Biomarkers of Environmental Contamination. CRC Press, Boca Raton, FL

McCarthy JF Shugart LR (1990) Biological markers of environmental contamination. In: McCarthy JF Shugart LR (eds.) Biomarkers of Environmental Contamination. CRC Press, Boca Raton, FL, p $1-12$

McCarthy JF, Jimenez BD, Shugart LR, Sloop FV, Oikari A (1990) Biological markers in animal sentinels: laboratory studies improve interpretation of field data. In: In Situ Evaluation of Biological Hazards of Environmental Pollutants. Springer, Boston, $\mathrm{p}$ 163-175

Shugart LR (1990) Biological monitoring: testing for genotoxicity. In: McCarthy JF Shugart LR, Biomarkers of Environmental Contamination, Lewis Publishers, Boca Raton, FL, p 205-216

Shugart LR (1990) DNA damage as an indicator of pollutant-induced genotoxicity. In Landis WG, van der Schalie WH (eds.) Aquatic Toxicology and Risk Assessment: Thirteenth Volume, ASTM International, Philadelphia, p 348-355

Shugart LR (1990) 5-Methyl deoxycytidine content of DNA from bluegill sunfish (Lepomis macrochirus) exposed to benzo [a] pyrene. Environ Toxicol Chem 9:205-208

Shugart LR, Griest WH, Tan E, Guzman C, Caton JE, Ho CH, \& Thomkins BA (1990) TNT metabolites in animal tissues. (Report No. ORNL/M-1336) Oak Ridge National Lab, Oak Ridge, TN

Shugart LR, Jimenez BD, McCarthy JF (1990) DNA damage as a biological marker in aquatic organisms exposed to benzo(a)pyrene. In: Cooke M, Loening K, Merritt J (eds.) Proceedings, 11th International Symposium on Polynuclear Aromatic Hydrocarbons: Measurements, Means, and Metabolism. Battelle Press, Columbus, OH USA, p 839-846

Shugart L, McCarthy J, eds. (1990) Use of Biomarkers for Assessment of Environmental Contaminant Exposure. CRC Press, Boca Raton, FL

Adams SM, Shepard KL, Greeley Jr MS, Jimenez BD, Ryon MG, Shugart LR, McCarthy JF, Hinton DE (1989) The use of bioindicators for assessing the effects of pollutant stress on fish. Marine Environ Res 28:459-464

Adams SM, Shugart LR, Southworth GR, Hinton DE (1990) Application of bioindicators in assessing the health of fish populations experiencing contaminant stress. In: McCarthy JF, Shugart LR (eds.) Biomarkers of Environmental Contaminantion. CRC Press, Boca Raton, FL, p 333-353

McCarthy JF, Jacobson DN, Shugart LR, Jimenez BD (1989) Preexposure to 3-methylcholanthrene increases benzo [a] pyrene adducts on DNA of bluegill sunfish. Marine Environ Res $28: 323-328$

McCarthy JF, Adams SM, Jimenez BD, Shugart LR (1989) Environmental monitoring of biological markers in animals and plants. In: Nobel RD, Martin JR, Jennsen KF (eds.) Air Pollution Effects on Vegetation, Including Forest Ecosystems: Proceedings of the Second US-USSR Symposium. Northeastern Forest Experiment Station, Broomall, PA, p 187-196

Shugart LR, Adams SM, Jiminez BD, Talmage SS, McCarthy JF (1989) Biological markers to study exposure in animals and bioavailability of environmental contaminants. In: Rhoda GM, Wang C, Franklin C, Honeycutt R, Reinert J (eds.) Biological Monitoring for Pesticide Exposure, American Chemical Society, Washington, DC, p 85-97

Shugart LR, Gustin MK, Laird DM, Dean DA (1989) Susceptibility of DNA in aquatic organisms to strand breakage: effect of X-rays and gamma radiation. Marine Environ Res 28:339-343
Martineau D, Lagace A, Bel P, Higgins R, Armstrong D, Shugart LR (1988) Pathology of stranded beluga whales (Delphinapterus leucas) from the St. Lawrence Estuary, Quebec, Canada. J Comparat Pathol 98:287-310

McCarthy JF, Shugart LR, Jimenez BD (1988) Biological markers in wild animal sentinels as predictors of ecological and human health effects from environmental contamination. In: Gehrs CW (ed) Proceedings, Eighth ORNL Life Science Symposium on Biological Indicators: Exposures and Effects, Knoxville, TN. Oak Ridge National Laboratory, Oak Ridge, TN, USA, p 34-42

Shugart L (1988) An alkaline unwinding assay for the detection of DNA damage in aquatic organisms. Marine Environ Res 24:321-325

Shugart LR (1988) Quantitation of chemically induced damage to DNA of aquatic organisms by alkaline unwinding assay. Aquat Toxicol 13:43-52

Shugart LR (1988) Biological monitoring using cellular macromolecules. Preprints of Papers Presented at National Meeting, Division of Water Air and Waste Chemistry. vol. 28, American Chemical Society, Washington, D.C., p. 2

Shugart LR, Jimenez BD, McCarthy JF (1988) Analysis of adduct formation in the bluegill sunfish exposed to benzo (a) pyrene. Aquatic Toxicology 11:413-414

Suter II, Gustin MK, Floit SB, Barnthouse LW, Shugart LR, Jimenez BD, McCarthy JF (1988) Investigations of relationships between oil field materials and practices and wildlife: Progress report, May 1988-October 1988 (Report No. ORNL/M-659) Oak Ridge National Laboratory, Oak Ridge, TN

Recio L, Shugart LR, Hsie AW (1987) The relationship between benzo (a) pyrene diol-epoxide-DNA adducts and mutagenicity in the CHO/HPGRT assay. Toxicol Sci 8:243-252

Shugart LR, Adams SM, Jimenez BD, Talmage SS, McCarthy JF (1987). Biological markers in animals can provide information on exposure and bioavailability of environmental contaminants, (Report No. CONF-8708254-1). Oak Ridge National Laboratory, Oak Ridge, TN, USA

Shugart L, McCarthy J, Jimenez B, Daniels J (1987) Analysis of adduct formation in the bluegill sunfish (Lepomis macrochirus) between benzo [a] pyrene and DNA of the liver and hemoglobin of the erythrocyte. Aquatic Toxicol 9:319-325

Shugart L (1986) Quantifying adductive modification of hemoglobin from mice exposed to benzo [a] pyrene. Analy Biochem 152:365-369

Shugart L (1985) Quantitating exposure to chemical carcinogens: in vivo alkylation of hemoglobin by benzo [a] pyrene. Toxicology 34:211-220

Shugart L, Kao J (1985) Examination of adduct formation in vivo in the mouse between benzo (a) pyrene and DNA of skin and hemoglobin of red blood cells. Environ Health Perspect 62:223-226

Shugart L (1985) Covalent binding of benzo [a] pyrene diol epoxide to DNA of mouse skin: in vivo persistence of adducts formation. $\mathrm{J}$ Toxicol Environ Health Part A: Current Issues 15:255-263

Shugart L, Matsunami R (1985) Adduct formation in hemoglobin of the newborn mouse exposed in utero to benzo [a] pyrene. Toxicology 37:241-245

Kao J, Hall J, Shugart LR, Holl JM (1984) An in vitro approach to studying cutaneous metabolism and disposition of topically applied xenobiotics. Toxicol Appl Pharmacol 75:289-298

Shugart L, Kao J (1984) Effect of ellagic and caffeic acids on covalent binding of benzo [a] pyrene to epidermal DNA of mouse skin in organ culture. Int J Biochem 16:571-573

Rahn RO, Holl JM, Shugart LR (1983) Quantitative assay of low levels of benzo [a] pyrenediol epoxide bound to DNA by acid-induced liberation of tetrols followed by chromatography and fluorometric detection. Progress in Nucleic Acid Research and Molecular Biology 29:103-106 
Shugart L, Kao J (1983) Ellagic acid decreases benzo [a] pyrenebinding to epidermal DNA of mouse skin in organ-culture. Fed Am Soc Exp Biol 42:2258

Shugart L, Holl JM, Rahn RO (1983) Dosimetry of PAH skin carcinogenesis: covalent binding of benzo [a] pyrene to mouse epidermal DNA. Carcinogenesis 4:195-198

Shugart L, Rahn RO, Holl J (1983) Quantifying benzo (a) pyrene binding to DNA by fluorescent analysis. Polynuclear Aromatic Hydrocarbons: Formation Metabolism and Measurement 1087-1097

Kao JY, Shugart LR, Holland JM (1982). Evaluation of biohazards using skin in organ culture, (Report No. CONF-821048-9). Oak Ridge National Laboratory, Oak Ridge,TN, USA

Rahn RO, Chang SS, Holl JM, Shugart LR (1982) A fluorometric-HPLC assay for quantitating the binding of benzo [a] pyrene metabolites to DNA. Biochem Biophys Res Commun 109:262-268

Shugart L, Chastain B, Holl JM (1982) Poly (ADP-ribosylation) in N, $\mathrm{N}$-diethylnitrosamine-treated mice. Int J Biochem 14:231-233

Shugart L (1982) A study of the kinetic mechanisms of two enzymes involved in the metabolism of adenosylmethionine. In Usdin E, Borchard RT, Creveling CR (eds.) Biochemistry of S-Adenosylmethionine and Related Compounds, Palgrave Macmillan London p 379-384

Shugart L, Mahoney L, Chastain B (1981) Kinetic studies of Drosophila melanogaster methylthioadenosine nucleoside phosphorylase. Int J Biochem 13:559-564

Shugart L (1979) Identification of fluorescent derivatives of adenosylmethionine and related analogues with high-pressure liquid chromatography. J Chromatogr 174:250-253

Shugart L, Chastain B (1979) $\mathrm{m} / \mathrm{sup} 7 /$ Guanosine in tRNA of Escherichia coli. Int J Biochem 10:155-157

Shugart L, Chastain B (1979) Escherichia coli tRNA (uracil-5)-methyltransferase: inhibition by analogues of adenosylhomocysteine. Enzyme 24:353-357

Shugart L, Tancer M, Moore J (1979) Methylthioadenosine nucleoside phosphorylase activity in Drosophila melanogaster. Int J Biochem 10:901-904

Bell JB, Jacobson KB, Shugart LR (1978) Multiple isoacceptor forms of several transfer ribonucleic acids in a mutant yeast strain. Canad J Biochem 56:51-59

Shugart L (1978) Kinetic studies of Escherichia coli transfer RNA (uracil-5-)-methyltransferase. Biochemistry 17:1068-1072

Shugart L, Chatain B (1977) tRNA methyltransferases in Escherichia coli during methionine starvation. FEMS Microbiol Lett 2:11-14

Shugart L (1976) Selective methylation: an incorrect hypothesis. J Bacteriol 126:1009-1011

Shugart L, Stulberg MP (1974) Isolation, purification, and methylation of undermethylated tRNA Phe from an RCrel mutant of Escherichia coli. Methods Enzymol 29:492-502

Shugart L, Stulberg MP (1974) Extent of methylation and the biological activity of phenylalanine tRNA (Report No. CONF-7405251). Oak Ridge National Laboratory, Oak Ridge, TN, USA
Shugart L (1973) Selective methylation of newly synthesized transfer RNA from a rel- mutant of Escherichia coli during methionine starvation. Biochem Biophys Res Commun 53: $1200-1204$

Waters LC, Shugart L, Yang WK, Best AN (1973) Some physical and biological properties of 4-thiouridine-and dihydrouridinedeficient tRNA from chloramphenicol-treated Escherichia coli. Arch Biochem Biophys 156:780-793

Pal BC, Shugart LR, Isham KR, Stulberg MP (1972) Modification of 4-thiouridine and phenylalanine transfer RNA with parachlormercuribenzoate. Arch Biochem Biophys 150:86-90

Shugart L (1972) Effect of selective chemical modification of 4-thiouridine of phenylalanine transfer ribonucleic acid on enzyme recognition. Arch Biochem Biophys 148:488-495

Shugart L (1972) A possible age-related modification of phenylalanine transfer RNA from wheat tissue. Exp Gerontol 7:251-262

Shugart L, Novelli GD (1971) Modification of reversed-phase column chromatography for rapid isolation and identification of formylmethionyl-tRNA. Methods Enzymol 20:35-39

Stulberg MP, Shugart LR (1971) Response of modified phenylalanine transfer RNA to recognition by phenylalanyl transfer RNA synthetase. Cancer Res 31:671-674

Epler JL, Shugart LR, Barnett WE (1970) N-formylmethionyl transfer ribonucleic acid in mitochondria from Neurospora. Biochemistry 9:3575-3579

Shugart L, Chastain B, Novelli GD (1969) Use of reversed-phase column chromatography for rapid isolation and identification of formylmethionyl transfer RNA. Biochimica et Biophysica Acta (BBA). Nucleic Acids Protein Synthesis 186:384-386

Shugart L, Stulberg MP (1969) Borohydride reduction of phenylalanine transfer ribonucleic acid: effect on enzyme recognition. J Biol Chem 244:2806-2808

Shugart L, Chastain B, Novelli GD (1969) A chromatographically different form of the formyl-accepting methionine transfer RNA from Escherichia coli. Biochem Biophys Res Commun 37:305-312

Shugart L, Chastain BH, Novelli GD, Stulberg MP (1968) Restoration of aminoacylation activity of undermethylated transfer RNA by in vitro methylation. Biochem Biophys Res Commun 31:404-409

Shugart L, Novelli GD, Stulberg MP (1968) Isolation and properties of undermethylated phenylalanine transfer ribonucleic acids from a relaxed mutant of Escherichia coli. Biochimica et Biophysica Acta (BBA): Nucleic Acids Protein Synthesis 157:83-90

Shugart LR, Beck RW (1966) Occurrence and distribution of proteinase of Streptococcus faecalis var liquefaciens. J Bacteriol 92:338-341

Beck RW, Shugart LR (1966) Molar growth yields in Streptococcus faecalis var. liquefaciens. J Bacteriol 92:802-803

Shugart LR, Beck RW (1964) Purification and activity of proteinase of Streptococcus faecalis var. liquefaciens. J Bacteriol 88:586-590 